\title{
Estimating Water Retention in Post-mining Excavations Using LiDAR ALS Data for the Strzelin Quarry, in Lower Silesia
}

\author{
Bartosz Jawecki ${ }^{1} \cdot$ Paweł B. Dąbek ${ }^{2} \cdot$ Katarzyna Pawęska $^{3} \cdot$ Xiangdong Wei $^{4}$
}

Received: 12 April 2017 / Accepted: 26 February 2018 / Published online: 3 March 2018

(c) The Author(s) 2018. This article is an open access publication

\begin{abstract}
A digital terrain model of the Strzelin granite quarry was created from ISOK project data obtained from airborne laser scanning (ALS). Based on 2009, 2012, and 2014 data, the volume of water in the Strzelin quarry's two excavations were determined. Additionally, the predicted volume of retained water after mining ceases was calculated, assuming a water level of $150.0 \mathrm{~m}$ a.s.1. In 2014 , the two reservoirs retained, respectively, $\approx 0.14$ and 0.01 million $\mathrm{m}^{3}$ of water. If the two pits are eventually connected, $\approx 6.6$ million $\mathrm{m}^{3}$ of water could be retained. Including the 2014 water volume as a small-scale retention basin would increase the volume of retained water in the Ślęza catchment and Strzelin County by 19.0\%, and 34.2\%, respectively. The hypothetical reservoir created after mining ends would increase small-scale (reservoir and pond) retention $\approx 8$ times in the Ślęza catchment and $\approx 15$ times in the County, constituting a significant improvement.
\end{abstract}

Keywords Water reclamation $\cdot$ Small-scale water retention $\cdot$ GIS $\cdot$ Digital terrain model (DTM) $\cdot$ ISOK project

\section{Introduction}

Poland's domestic water resources are relatively low, for a European country, with a mean annual surface water discharge of $\approx 61.2 \mathrm{~km}^{3}$ (GUS 2015). The water resource index

Bartosz Jawecki

bartosz.jawecki@upwr.edu.pl

Paweł B. Dąbek

pawel.dabek@upwr.edu.pl

Katarzyna Pawęska

katarzyna.paweska@upwr.edu.pl

Xiangdong Wei

xiangdongw@126.com

1 Institute of Landscape Architecture, Wrocław University of Environmental and Life Sciences, ul. Grunwaldzka 55, 50-357 Wrocław, Poland

2 Institute of Environmental Protection and Development, Wrocław University of Environmental and Life Sciences, pl. Grunwaldzki 24, 50-363 Wrocław, Poland

3 Institute of Environmental Engineering, Wrocław University of Environmental and Life Sciences, pl. Grunwaldzki 24, 50-363 Wrocław, Poland

4 Department of Environmental Sciences, School of Resource \& Environment, Hunan Agricultural University, Changsha 410128, Hunan, China averages $1590 \mathrm{~m}^{3}$ per year per person, but in dry years this index falls to $1100 \mathrm{~m}^{3}$ per year per person (Walczykiewicz 2014). In many cases, the water is of poor quality. It is estimated that the water resources in Europe amount, on average, to $\approx 4750 \mathrm{~m}^{3}$ per year per person. So it is important to control and protect Poland's water resources, which is done, in part, by water retention in reservoirs (Łabędzki 2016). Still, Poland's $\approx 100$ reservoirs constitute less than $6.0 \%$ of the area's annual discharge. This situation does not provide sufficient protection against periodic water surpluses or deficits (GUS 2015). In comparison, about 7000 large reservoirs exist across Europe, with a total capacity representing about $20.0 \%$ of Europe's freshwater resources (EEA 2009).

In Poland, there are also $\approx 31,300$ small-scale retention reservoirs, with a total volume of $\approx 0.8$ billion $\mathrm{m}^{3}$ (GUS 2015). Reservoirs with a volume of up to 5 million $\mathrm{m}^{3}$ are considered small-scale retention reservoirs (Drabiński et al. 2006; Mosiej 2014; Mosiej and Bus 2015). Natural ways to improve small-scale retention include: changes in land use (e.g. forestation, proper spatial arrangement and types of development); increasing soil retention and reducing soil erosion; and preservation and revitalization of wetlands. The technical forms of water retention include: water reservoirs of different sizes and purposes (ponds, field agricultural reservoirs, fire water reservoirs, oxbow lakes, moats, mine/quarry pits) and installations that enable water level 
adjustment (weirs, gates, barrages) as well as flood polders, inter-dike areas, and properly functioning drainage systems (EC 2012; Gomez et al. 2013; Mioduszewski et al. 2014).

The objectives of small-scale water retention may differ, but they generally benefit the environment and influence the water balance of a catchment, increase its water resources, decrease flood-stages, increase low flows, contribute to water quality improvement, and enrich a landscape's natural value (Jawecki 2004; Łabędzki 2016; Mioduszewski et al. 2014; Wiatkowski et al. 2013).

In Poland, $\approx 26,500$ ha of land are used for opencast mining (Kasztelewicz and Kaczorowski 2009). After mining ceases, the potential creation of pit or quarry lakes is particularly important to water management. Many artificial lakes have formed in former clay, sand, and gravel pits, quarries, and opencast lignite mines when mining ceased (Jawecki 2012; Jawecki et al. 2014; Schultze et al. 2010). In recent decades, hundreds of such lakes have been created in many countries around the world (Doupé and Lymbery 2005; Duval et al. 2009; McCullough 2008; Schultze et al. 2010; Soni et al. 2014; Townsend et al. 2009). According to estimates, $\approx 10.0 \%$ of formerly mined land is used in this way (Kasztelewicz et al. 2010).

Such lakes develop when dewatering efforts stop and the excavated areas slowly fill with groundwater, rainfall, and surface runoff (Hinwood et al. 2012; Kleeberg and Grüneberg 2005; McCullough 2008). This process may last for months, years, or even decades and its pace depends on the size of the excavation, the hydrogeological conditions, and the geological structure of the mine and its surroundings (Kumar et al. 2016; Schultze et al. 2010). Sometimes, water from rivers or streams is used to quickly flood the mine (Schultze et al. 2010; Singleton et al. 2013).

The lakes thus created can have different depths, surface areas and volume, depending on the excavated raw material and the mining technology (Clews et al. 2014; Kumar et al. 2016; McCullough and Lund 2006; Molenda 2006; Schultze et al. 2010; Singleton et al. 2013). The methods of determining the geomorphological parameters of the excavation depend on its accessibility and on the depth of the water reservoir (if it exists). The volume of the excavation at a given moment can be calculated using traditional geodesic methods or modern techniques, such as the GNSS technology and RTK method (Labant et al. 2013; Polak et al. 2014). If LiDAR data are available or possible to obtain, the geomorphological parameters of the excavation can be determined by terrestrial (TLS) or airborne laser scanning (ALS) or other photogrammetric measurement (Wajs 2015; Witt 2016). The bathymetric measurements are required to determine the parameters of the submerged terrain (Deus et al. 2013).

Water in flooded mines can be used for various purposes, including: recreation and tourism (bathing, swimming, diving, fishing, surfing, boating, canoeing, water skiing), wildlife habitat, aquaculture and fish farming, water management (water storage, storage of high flood, addition to low-water), drinking and industrial water reservoirs, or storage of irrigation water for agriculture and horticulture (Axler et al. 1996; Ceppi et al. 2014; Doupé and Lymbery 2005; Jawecki 2012; McCullough 2008; McCullough and Lund 2006; Ravazzani et al. 2011; Schultze et al. 2010). The potential use of mine and quarry lake water depends on both water quantity and quality (Axler et al. 1996; Clews et al. 2014; Doupé and Lymbery 2005; Kumar et al. 2016; McCullough 2008; McCullough and Lund 2006; Schultze et al. 2010).

Adapting to climate changes, including counteracting the effects of floods and droughts (especially in the agriculture and water management sectors) and decreasing the water deficit are important elements of Poland's water management policy. Increasing the volume of retained water by creating various forms of small-scale retention can increase water resources and improve the rational management of such resources, especially from a local and regional perspective (Łabędzki 2016; Linnerooth-Bayer et al. 2015; Ministry of the Environment 2013; Mioduszewski et al. 2014; Szwed 2015). This is particularly important in areas with limited water resources (Ceppi et al. 2014; Kumar et al. 2009; Ravazzani et al. 2011).

The aim of this study was to determine the volume of water retained in the Strzelin quarry in the years 2009, 2012, and 2014, assuming that both of its excavations were filled with water up to $150.0 \mathrm{~m}$ a.s.l. (above sea level). We also estimated the volume of water that could be hypothetically retained if the pillar separating the pits were removed and the combined pit was filled with water to the assumed same level. We also evaluated the potential of applying LiDAR ALS data to estimate water retention. The results were used to determine the influence of water retention in the Strzelin quarry on the small-scale reservoir retention resources of the area.

\section{Material and Methodology}

The Strzelin granite quarry is located in the Lower Silesian Voivodeship, Poland, in the western part of the town of Strzelin. Granite and gneiss from the Strzelin deposit are excavated in two (Strzelin I and Strzelin II) pits (Fig. 1). The surface area of the deposit is 31.83 ha and the excavation area is $47.93 \mathrm{ha}$, with a mining area of $\approx 129.7 \mathrm{ha}$. The planned direction of excavation reclamation was forestation (MIDAS 2012). The Strzelin I pit has a surface area of $\approx 10.0$ ha, a depth of $\approx 113.9 \mathrm{~m}$ (to the water level, which in 2009 was stabilized at $66.0 \mathrm{~m}$ a.s.l.) and a volume of $\approx 5.1$ million $\mathrm{m}^{3}$, while Strzelin II has, respectively, $\approx 12.3 \mathrm{ha}$, $\approx 56.6 \mathrm{~m}$ 


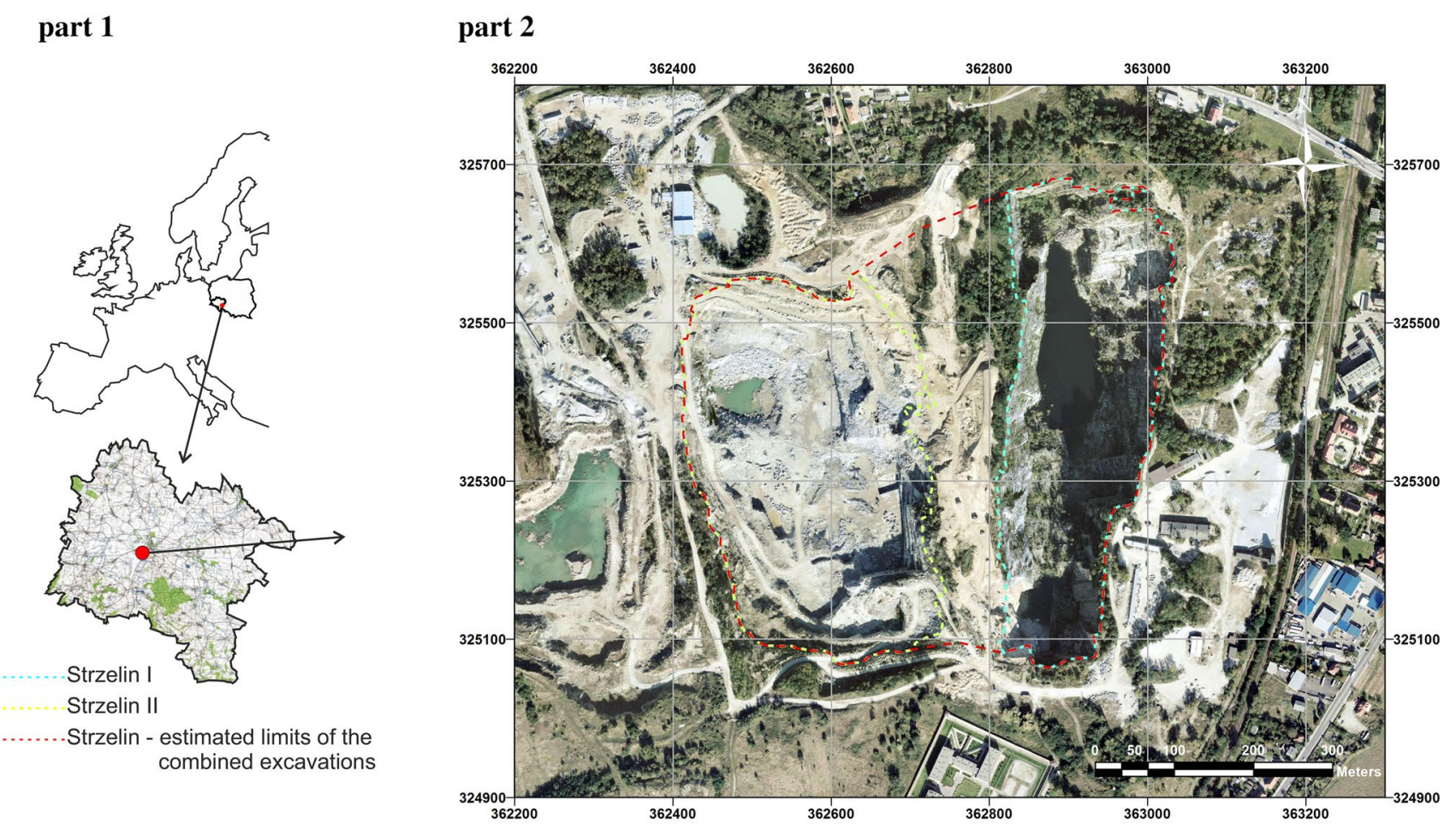

part 3

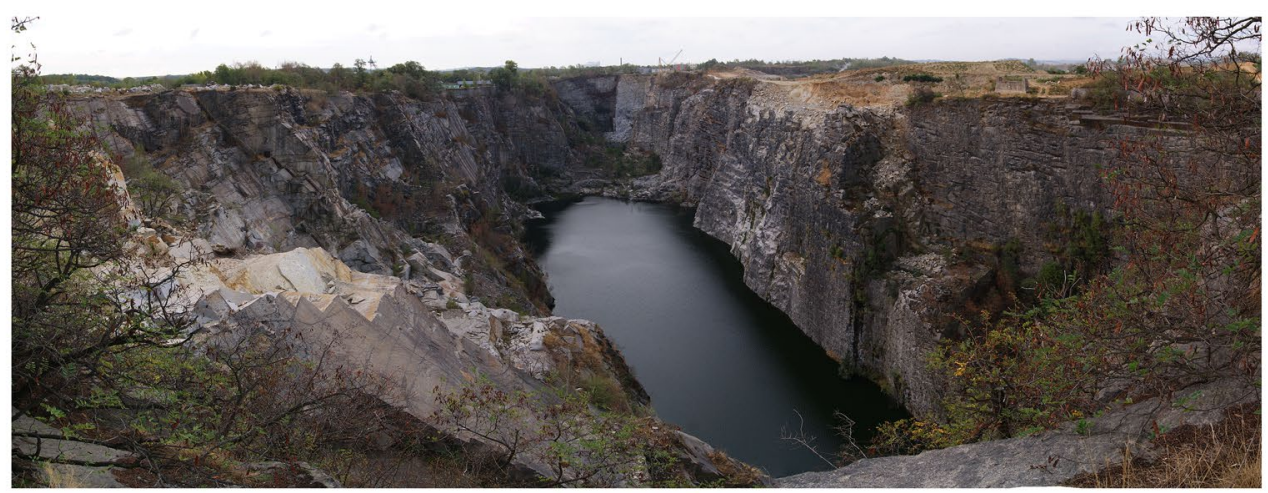

part 4

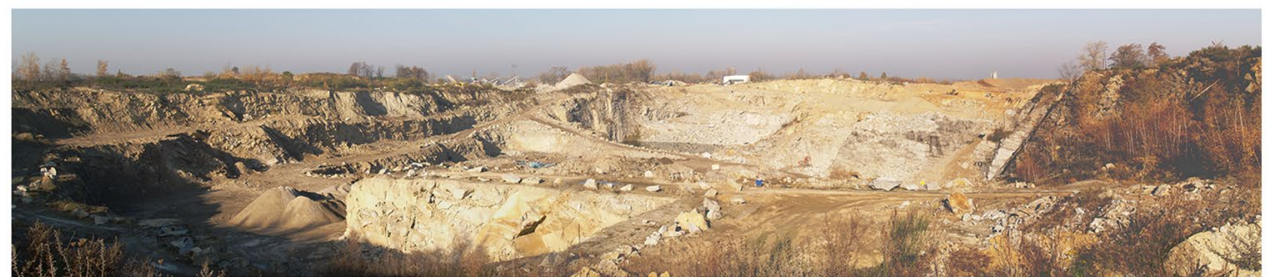

Fig. 1 The location and photographic documentation of the Strzelin Granite Quarry (photos: B. Jawecki, map source on license, coordinate system PUWG-92, figure-own compilation)

(to the water level, which in 2014 was stabilized at $130.0 \mathrm{~m}$ a.s.1.), and $\approx 2.4$ million $\mathrm{m}^{3}$ (Table 1 ). The quarries are open pits and mining is conducted using the longwall system. The industrial resources estimated at the end of 2015 amounted to 59.8 million tonnes $(\mathrm{t})$, with annual excavation amounting to $\approx 1.1$ million $t$ (Szuflicki et al. 2016). The excavated rock is used to manufacture blocks, crushed stone and crushedstone aggregate for use in constructing roadworks, buildings, and railways. The excavated volume is increased by 0.375 million $\mathrm{m}^{3}$ annually based on the excavated amount and the bulk density of the rock (granite $-2.64 \mathrm{~g} / \mathrm{cm}^{3}$, gneiss $-2.67 \mathrm{~g} / \mathrm{cm}^{3}$; MIDAS 2012). 
Table 1 Characteristics of the Strzelin I and II quarries and their potential characteristics if they were connected

\begin{tabular}{|c|c|c|c|c|}
\hline & Unit & Strzelin I & Strzelin II & Potential pit \\
\hline \multicolumn{5}{|l|}{ Ordinate of excavation edge } \\
\hline Adopted for calculations & $\mathrm{m}$ a.s.l & 170.0 & 170.0 & 170.0 \\
\hline Highest & m a.s.l & 179.9 & 186.6 & 186.6 \\
\hline Lowest & m a.s.l & 169.3 & 169.4 & 169.3 \\
\hline \multicolumn{5}{|l|}{ Ordinate of the excavation bottom } \\
\hline Lowest (water level in the sump) & m a.s.l & 66.0 & 130.0 & 66.0 \\
\hline \multicolumn{5}{|l|}{ Depth of the excavation } \\
\hline To $170.0 \mathrm{~m}$ a.s.l & $\mathrm{m}$ & 103.4 & 40.0 & 103.4 \\
\hline To the highest ordinate of the edge & $\mathrm{m}$ & 113.9 & 56.6 & 120.6 \\
\hline To the lowest ordinate of the edge & $\mathrm{m}$ & 103.3 & 39.4 & 103.3 \\
\hline Surface area of the excavation (at $170.0 \mathrm{~m}$ a.s.l.) & ha & 9.71 & 12.56 & 27.45 \\
\hline Volume of the excavation ${ }^{\mathrm{a}}$ (at $170.0 \mathrm{~m}$ a.s.1.) & million $\mathrm{m}^{3}$ & 5.097 & 2.364 & 11.588 \\
\hline
\end{tabular}

${ }^{\mathrm{a}}$ Volume calculated to the bottom and to the water level in the sump in the excavation
The geological documentation of the Strzelin deposit (Balawajder 1988) states that no inflow of water was noted during exploratory drilling, although the western part of the lode (where the Strzelin II pit is located) contained three water reservoirs with a total volume of $\approx 270,000 \mathrm{~m}^{3}$ (including one with a volume of $\approx 253,000 \mathrm{~m}^{3}$ ). Strzelin I contains a bailed sump (a reservoir of mine water, which is drained by suction pumps; Glapa and Korzeniowski 2005), with a volume of $\approx 100 \mathrm{~m}^{3}$. The water levels in the reservoirs fluctuated $\approx 1.5 \mathrm{~m}$, depending on the amount of precipitation and evaporation, but was not recorded.

Water flows into the Strzelin I and II pits from rainfall, surface and sub-surface runoff and water transfer between the pits. The water level in the Strzelin II excavation, based on a map from 1983, reached $150.0 \mathrm{~m}$ a.s.l. This ordinate was assumed to be the target water level in the quarry after the end of mining. Currently, a water reservoir has developed in the Strzelin I pit, while in Strzelin II, the sump is periodically drained.

According to the hydrographical map of Poland (NWMA 2010), the Strzelin quarry is located in the catchment of the Ślęza River (located in WR08 Bystrzyca water balance catchment), in the Oder River basin. According to the small-scale water retention programme of the Lower Silesian Voivodeship (Drabiński et al. 2006; RWMA 2016), the total volume of reservoir and pond retention in the Ślęza catchment is 0.809 million $\mathrm{m}^{3}(0.552$ million $\mathrm{m}^{3}$ in reservoirs and 0.257 million $\mathrm{m}^{3}$ in ponds). The quarry is situated in the WR08 Bystrzyca water balance catchment (balance region W-VIII Bystrzyca Ślęza; PIG 2007; RWMA 2016), which includes 7 reservoirs with a total retention volume of 16.19 million $\mathrm{m}^{3}$. In administrative terms, the quarry is located in Strzelin County, where reservoir and pond retention amounted to $449,800 \mathrm{~m}^{3}$ (as of Dec. 31st, 2004; Drabiński et al. 2006), based on reservoirs of at least 1 ha in area. According to the County's water law permits for the years 2005-2015, as of Dec. 31 st, 2015, the County now contains a total of 46 reservoirs and ponds with a total volume of 1.64 million $\mathrm{m}^{3}$; this total now includes facilities with a surface area less than 1 ha.

The study was based on LiDAR data obtained under the ISOK project (Informatics System for the Protection of the Country from extraordinary dangers), with the use of airborne laser scanning. The ISOK project was created in response to the high risk of flooding in Poland, especially following the flood damages in the Oder River basin in 1997 and along the Vistula River in 2010. ALS data were gathered from 2010 to 2013. First, measurements were obtained for areas with a risk of flooding (Wężyk et al. 2015). The density of the data (in the form of a point cloud) corresponded to 4 points per $\mathrm{m}^{2}$ for non-urban areas and 12 points per $\mathrm{m}^{2}$ for urban areas. The ALS data point clouds were then subjected to a classification process and finally, a digital terrain model (DTM) and digital surface model (DSM) were generated from the respective classes. The classification was performed in compliance with Standard 1.2 of the LAS file format issued in 2008 by the American Society for Photogrammetry and Remote Sensing (APSRS). Data in the format of LAS files contain information about the class of the given object (8 classification classes) and geographical coordinates of each point. The accuracy of point classification is at least $95.0 \%$ and the height means error falls within a range of up to $0.2 \mathrm{~m}$. All height data were prepared in the flat rectangular coordinate system "PUWG-92" (EPSG: 2180); the heights refer to the "Kronsztadt 86" normal height system.

The LiDAR ALS data from the ISOK project are available free of charge for research and teaching purposes from the Head Office of Land Surveying and Cartography resources. The LiDAR flight was made on the 27-28.04.2012, from a height of $715 \mathrm{~m}$ above terrain surface in an E-W direction. The obtained density of the points cloud, after equalization 
and classification, is 4 points per $\mathrm{m}^{2}$, while the height accuracy is $\leq 0.15 \mathrm{~m}$.

By interpolation of the point cloud in the ArcGIS 10.3 software, a digital terrain model (DTM) was created for the Strzelin I and II excavations in a ESRI GRID format model with a regular square grid and a spatial resolution of $0.5 \mathrm{~m}$. Due to the ALS technology, the prepared DTM presents only the terrain above the water level, which was situated at 75.00 and $134.00 \mathrm{~m}$ a.s.1., respectively, in the Strzelin I and II pits in 2012, when the data were obtained. The information of the Strzelin I excavation terrain relief to $66.0 \mathrm{~m}$ a.s.l. was supplemented based on the analogue geodesic map from 2009. The water level was assumed on $66.0 \mathrm{~m}$ a.s.l. For 2014, the water level in the pits were assumed based on orthophotomaps created during that period, assuming a water level of $85.0 \mathrm{~m}$ a.s.l. for Strzelin I and $130.00 \mathrm{~m}$ a.s.l. for Strzelin II (the excavation between 134.0 and $130.0 \mathrm{~m}$ a.s.l. was based on the analogue map). A terrain level of $170.0 \mathrm{~m}$ a.s.l. was assumed as the upper edge of the excavation, pursuant to contours generated from the DTM. This height corresponds to the visual edge of the excavation area in the orthophotomap. Further analyses were conducted with use of Surfer10 software, where the DTM was imported in GRID format from the ArcGIS environment.

\section{Results}

In addition to atmospheric precipitation and surface and subsurface runoff, the quarry workers indicate that the Strzelin II excavation is also supplied with water that flows through cracked rock from the Mikoszów excavation that is adjacent to the west (Fig. 1). Additionally, water flows from Strzelin
II to Strzelin I. As a result, and due to the fact that the pumping of water was periodically neglected, the sump in the Strzelin I pit increased its size, becoming a reservoir. By 2009, the estimated volume of retained water was 0.005 million $\mathrm{m}^{3}$ (Fig. 2) and the area covered by water in this reservoir (at $66.0 \mathrm{~m}$ a.s.1., Fig. 3) was 0.12 ha. In 2012, the area of the water (75.0 m a.s.1., Fig. 3) was 0.58 ha, while the volume of retained water had increased to 0.033 million $\mathrm{m}^{3}$ (Fig. 2). Thus, in 3 years, its area had increased fivefold and the volume of retained water had increased sevenfold. In 2014, the area of the reservoir ( $85.0 \mathrm{~m}$ a.s.1., Fig. 3) was $1.48 \mathrm{ha}$, and the volume of retained water was 0.141 million $\mathrm{m}^{3}$ (Fig. 2), a 13- and 30-fold increase, respectively, compared to 2009. Basing on the DTM calculations with a spatial resolution of $0.5 \mathrm{~m}$ obtained from the ISOK project data, if the excavation was filled with water to its 1983 level (150.0 m a.s.1.), the area would be $7.93 \mathrm{ha}$, and the volume of retained water would be 3.344 million $\mathrm{m}^{3}$ (Fig. 2), a 68 -fold increase in area and a 714-fold increase in volume of retained water, compared to 2009.

The volume of water retained in the reservoir in the Strzelin I excavation in 2014 (at a water level of $85.0 \mathrm{~m}$ a.s.1.) increases the volume of small-scale pond and reservoir retention in Strzelin County by $31.2 \%$ (according to data from the Small-scale Retention Programme that covers facilities with an area $>1$ ha; Drabiński et al. 2006) and by $8.6 \%$ if one also includes those $<1$ ha. In hydrological terms, the volume of water in these excavations as of 2014 increases the water resources in the Ślęza catchment by $17.4 \%$ and in the WR08 Bystrzyca balance catchment by $0.9 \%$. Moreover, the potential water reservoir that would develop in the Strzelin I excavation if the water level reached $150.0 \mathrm{~m}$ a.s.l. would increase the small-scale reservoir and pond retention volume
Fig. 2 Current and planned water retention volume in the Strzelin quarry in the context of reservoir and pond retention in terms of the county and the catchment

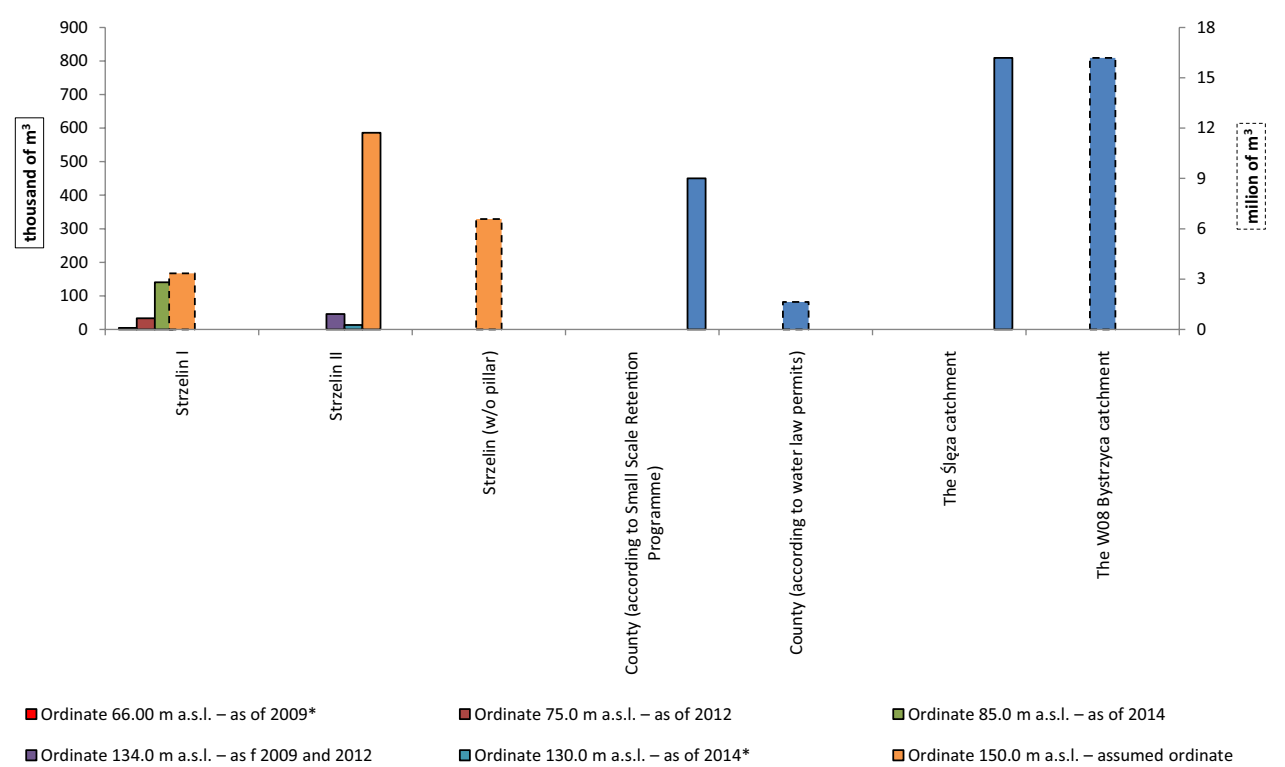

$\square$ Pond and reservoir retention 

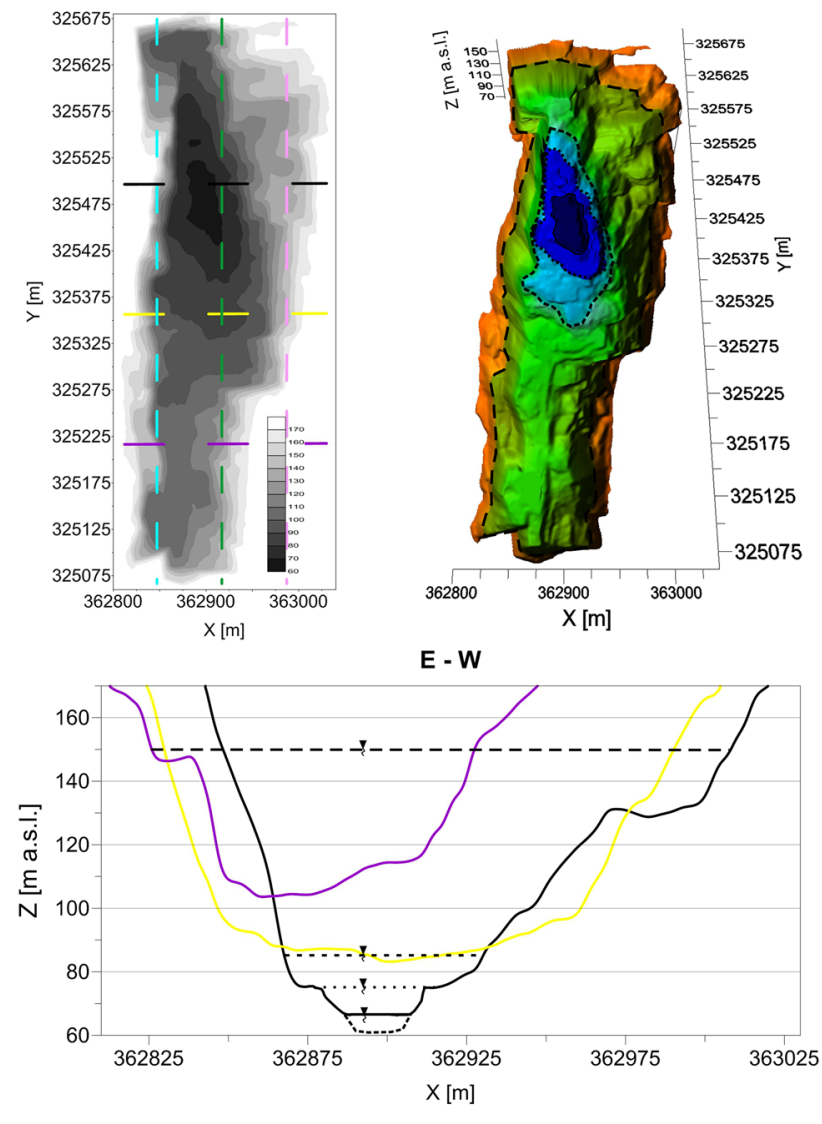

$\mathrm{S}-\mathbf{N}$

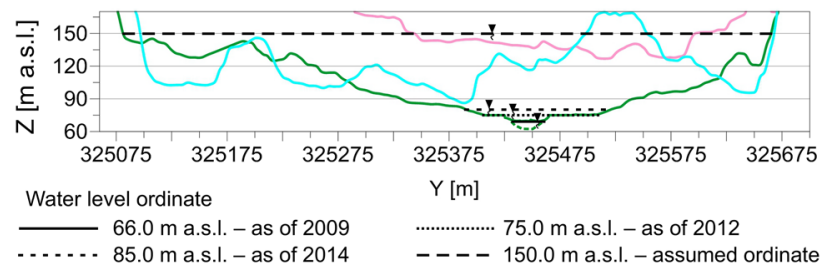

Fig. 3 DTM and cross-sections of the Strzelin I quarry with the ordinate of water level in the excavation (coordinate system PUWG-92, figure-own compilation)

in Strzelin County by sevenfold (based on the amount of water in reservoirs $>1$ ha) or twofold (based on the water law permit data). At the same time, it would increase the water resources in the Ślęza catchment fourfold and in the WR08 Bystrzyca balance catchment by $20.7 \%$.

In the Strzelin II excavation there is a sump from which the water is pumped and discharged (to the Pluskawa water course or to the Strzelin I excavation). In 2009 and 2012, the inundated area (134.0 m a.s.1., Fig. 4) was 1.19 ha, and the estimated volume of retained water was 0.046 million $\mathrm{m}^{3}$ (Fig. 2). In 2014, the area of the reservoir (130.0 $\mathrm{m}$ a.s.1., Fig. 4) was 0.26 ha, and the volume of retained water was 0.013 million $\mathrm{m}^{3}$ (Fig. 2). Due to the fact that water was pumped out of the excavation, the water level area decreased by $\approx 78.0 \%$ and the volume of the retained water fell by $\approx 70.0 \%$ compared to the year 2012. Basing on the DTM of the excavation, if the water level was maintained at the assumed target ordinate (150.0 $\mathrm{m}$ a.s.1., Fig. 4), the area of the reservoir would reach 5.65 ha, while the volume of retained water would total 0.586 million $\mathrm{m}^{3}$ (Fig. 2). Thus, the area of water would increase fivefold and the volume of the retained water 13 -fold.

The volume of water retained in the Strzelin II reservoir in 2014 (at $130.0 \mathrm{~m}$ a.s.1.) increases the volume of small-scale pond and reservoir retention in Strzelin County by $3.0 \%$ (considering reservoirs $>1$ ha) and by $0.8 \%$ (based on the water law permit data), in the Ślęza catchment by $1.7 \%$ and in the WR08 Bystrzyca balance catchment by $0.1 \%$. Moreover, the potential reservoir that would develop in Strzelin II if the water level reached $150.0 \mathrm{~m}$ a.s.l. would increase the volume of small-scale reservoir and pond retention in the Strzelin County by $130.2 \%$ (considering reservoirs of an area $>1$ ha) and by $35.7 \%$ (with respect to the water law permit data), in the Ślęza catchment by $72.4 \%$, and in the WR08 Bystrzyca balance catchment by $3.6 \%$.

The potential joining of Strzelin I and II, (by mining the granite pillar separating the two) and excavating Strzelin II up to the $130.0 \mathrm{~m}$ a.s.l. would create a single excavation with an area of 27.5 ha (Fig. 5) and a capacity of 11.6 million $\mathrm{m}^{3}$ (Table 1). Below $130.0 \mathrm{~m}$ a.s.1., the Strzelin I excavation would remain unchanged. A water reservoir with an area of 23.97 ha and a volume of 6.576 million $\mathrm{m}^{3}$ (Fig. 2) would emerge after the potential excavation had been filled with water up to $150.0 \mathrm{~m}$ a.s.l. (Fig. 5), increasing the pond and reservoir retention resources in Strzelin County 15-fold (considering the water retained in reservoirs $>1$ ha) and fourfold with respect to the water law permit data. However, it should be noted that, due to its volume, such a reservoir would no longer be a small-scale retention reservoir, as its capacity will exceed 5 million $\mathrm{m}^{3}$. The resources of retained water in the Ślęza catchment would increase eightfold, while the water retention resources in the WR08 Bystrzyca balance catchment would increase by $40.6 \%$.

\section{Discussion and Conclusions}

Including the volume of water retained in Strzelin I and II in the water retention balance would increase the volume of water retained in the WR08 Bystrzyca balance catchment by $0.9 \%$, in the Ślęza catchment by 19.0 and $34.2 \%$ in Strzelin County (considering reservoirs of an area $>1$ ha) and by 9.4\% (according to data from water law permits). The reservoir that would be created by joining the two pits and filling them with water up to $150.0 \mathrm{~m}$ a.s.l. would retain 6.576 million $\mathrm{m}^{3}$ of water, increasing small-scale retention in administrative and water balance regions. This might contribute to the improvement of the water balance (Kowalewski 2008; 
Fig. 4 DTM and cross-sections of the Strzelin II quarry with the ordinate of water level in the excavation (coordinate system PUWG-92, figure-own compilation)
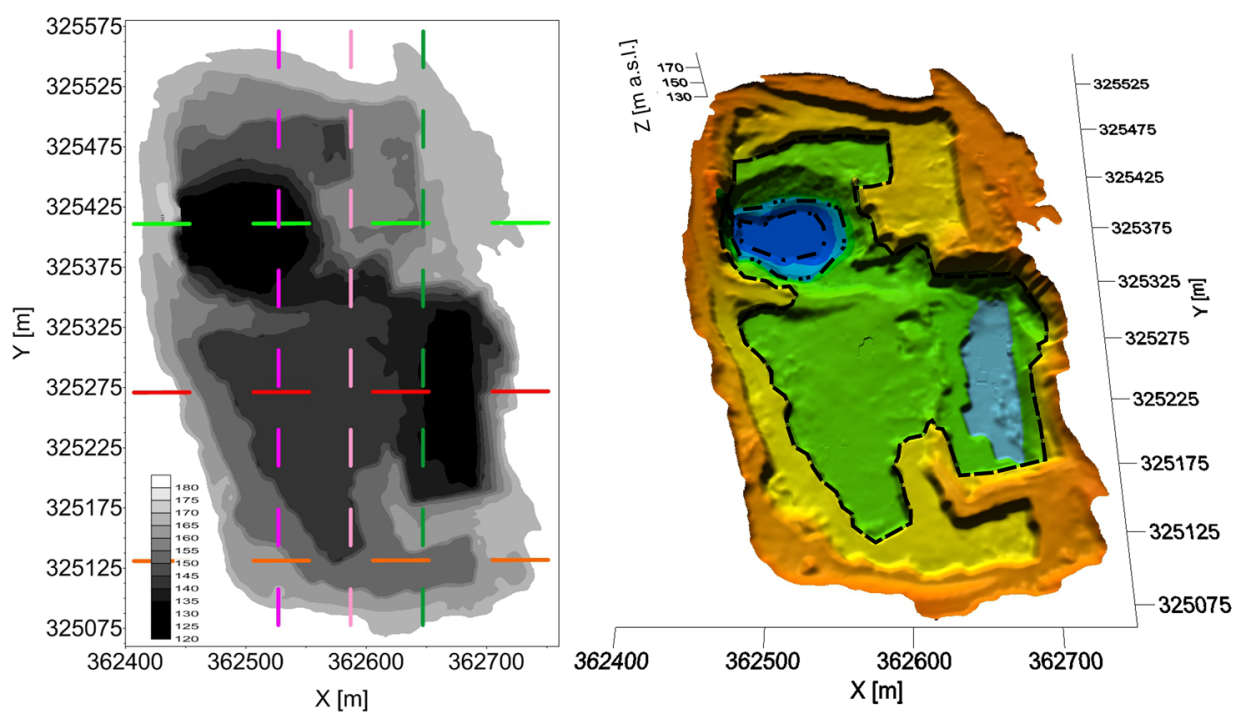

$\mathbf{E}-\mathbf{W}$
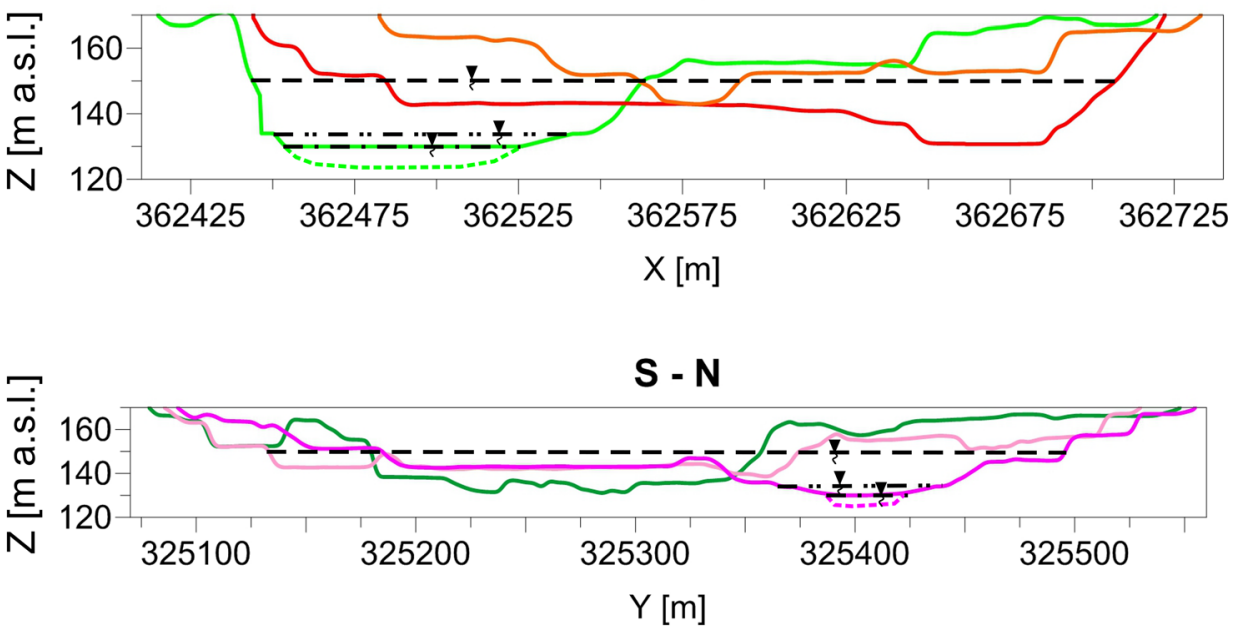

Water level ordinate

-.... - 134,00 m a.s.I. as of $2009 \& 2012-\cdot-\cdot 130,00 \mathrm{~m}$ a.s.I. as of 2014

- - - $\cdot 150,00 \mathrm{~m}$ a.s.l. assumed ordinate
Łabędzki 2016; Mosiej 2014) and mitigate the consequences of water deficits. Depending on the quality of the retained water, it may be used, among others, for irrigation purposes (the Strzelin County is an agricultural area), supplying rivers and streams in times of low water level, providing water to residents and to the industry and water recreation (Ceppi et al. 2014; Doupé and Lymbery 2005; Hinwood et al. 2012; Kumar et al. 2009; McCullough and Lund 2006; Ravazzani et al. 2011; Schultze et al. 2010; Singleton et al. 2013; Soni et al. 2014).

There are $\approx 80$ closed quarries and $\approx 270$ sand mines, gravel pits, and clay pits in Strzelin County. Some of them have become reservoirs, ranging from small, shallow, midfield or mid-forest ponds to medium-size reservoirs that are over ten and even up to several tens of meters deep. These may constitute an important element of the surface water balance of Strzelin County and of the Oława and Ślęza catchments in the Lower Silesian Voivodeship in the upperand mid-Oder water region. The contribution of water reservoirs created in post-mining excavations requires further studies in local, regional, national, and continental terms. In Poland, there are $\approx 40,054$ ha of land that was devastated and degraded by mining and quarrying $(0.13 \%$ of the surface area of Poland) (GUS 2015), of which $\approx 10.0 \%$ is being reclaimed as reservoirs (Kasztelewicz et al. 2010). The purpose of such activities includes limiting water deficits and the negative effects of droughts and floods, which is particularly important in areas characterized by low water resources (Ceppi et al. 2014; Doupé and Lymbery 2005; Kumar er al. 2009; Łabędzki 2016; Linnerooth-Bayer et al. 2015; McCullough and Lund 2006; Ministry of the Environment 
Fig. 5 DTM and cross-sections of the potential Strzelin quarry excavation that would emerge after joining both excavations, with the ordinate of water level in the excavation (coordinate system PUWG-92, figure-own compilation)
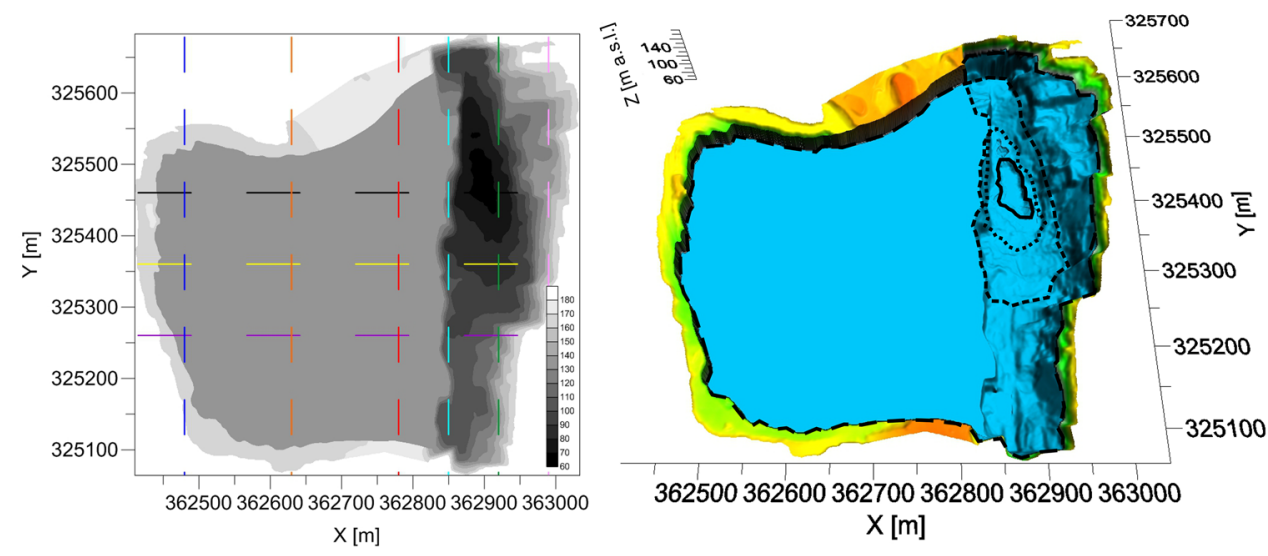

$E-W$
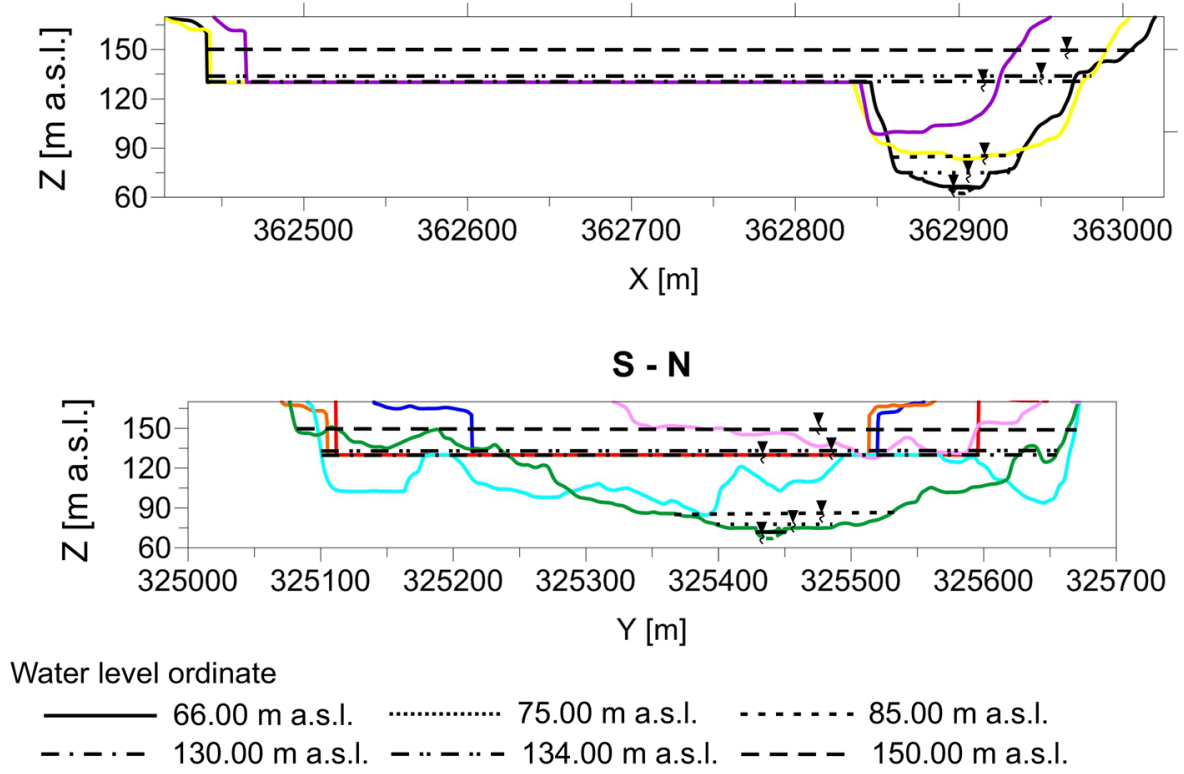

2013; Mosiej 2014; Ravazzani et al. 2011; Szwed 2015; Walczykiewicz 2014).

Following analysis of the ALS data obtained from the ISOK project in the form of a DTM in the Strzelin quarry area, we conclude the following:

1. The volume of water retained (as of 2014) in the Strzelin I and II pits $\left(0.154\right.$ million $\left.\mathrm{m}^{3}\right)$ is an important element of the reservoir retention balance, in terms of the Ślęza catchment, the WR08 Bystrzyca balance catchment, and Strzelin County. It had not previously been accounted for and significantly increases reservoir retention in the Strzelin County area.

2. Removing the pillar that separates the Strzelin I and II pits, and thus creating a single excavation after mining ceases, will create a water reservoir with an estimated volume of 6.576 million $\mathrm{m}^{3}$, which would increase water retention in the Ślęza catchment eightfold, in the WR08
Bystrzyca balance catchment by $\approx 40.0 \%$, and in Strzelin County fourfold.

3. Under favorable hydrogeological and geomorphological conditions, reclamation of excavations as reservoirs will increase the retention capacity of a catchment, while at the same time helping an area adapt to climate changes by counteracting the effects of droughts and floods.

4. As a large number of closed excavations of various sizes have been inundated in Strzelin County, i.e. water reclaimed, they may constitute an important element of the small-scale retention balance. However, determining the scale of such activities and their results requires further research and analysis.

5. The issue of using closed excavations as water retention reservoirs may also be important on the regional, national, and continental scale, since hydrographic divisions reach beyond administrative borders and because 
open-cast mines exist throughout much of and in many other locations.

6. The use of a high-resolution digital terrain model in connection with hydrogeological data is an efficient way to predict the volume of water that may be retained in excavations after the end of mining based on the assumption that the area will be water reclaimed.

Acknowledgements The study was based on: LiDAR ALS data (available free of charge for research and teaching purposes) from the Head Office of Land Surveying and Cartography resources on license No. DIO.7211.197.2016_PL_N (Paweł B. Dąbek, Wroclaw University of Environmental and Life Sciences, Institute of Environmental Protection and Development) and on map from the Marshal of Lower Silesia Voivodeship resources on license No. MGW.I.7522.524.2016_02_N and MGW-I.7522.129.2017_02_CL0 (Bartosz Jawecki, Wroclaw University of Environmental and Life Sciences, Institute of Landscape Architecture).

Open Access This article is distributed under the terms of the Creative Commons Attribution 4.0 International License (http://creativeco mmons.org/licenses/by/4.0/), which permits unrestricted use, distribution, and reproduction in any medium, provided you give appropriate credit to the original author(s) and the source, provide a link to the Creative Commons license, and indicate if changes were made.

\section{References}

Axler R, Larsen C, Tikkanen C, McDonald M, Yokom S, Aas P (1996) Water quality issues associated with aquaculture: a case study in mine pit lakes. Water Environ Res 68(6):995-1011

Balawajder J (1988) Dokumentacja Geologiczna Złoża granitu i gnejsu Strzelin, w kat. C1 + B (Geological Documentation. Granite and gneiss deposits in Strzelin, categories C1 + B). Wrocław (manuscript) (in Polish)

Ceppi A, Ravazzani G, Corbari C, Salerno R, Meucci S, Mancini M (2014) Real-time drought forecasting system for irrigation management. Hydrol Earth Syst Sc 18:3353-3366

Clews E, Low E, Belle CC, Todd PA, Eikaas HS, Ng PKL (2014) A pilot macroinvertebrate index of the water quality of Singapore's reservoirs. Ecol Indic 38:90-103

Deus D, Gloaguen R, Krause P (2013) Water balance modeling in a semi-arid environment with limited in situ data using remote sensing in Lake Manyara, East African Rift, Tanzania. Remote Sens 5:1651-1680

Doupé RG, Lymbery AJ (2005) Environmental risks associated with beneficial end uses of mine lakes in southwestern Australia. Mine Water Environ 24(3):134-138

Drabiński A, Radczuk L, Nyc K, Mokwa M, Olearczyk B, Markowska J, Bac-Bronowicz J, Chmielewska I, Jawecki B, Gromada O, Pikul K, Maczewska B, Goździk M (2006) Program małej retencji wodnej w województwie dolnośląskim (Programme of small-scale water retention in the lower Silesian Voivodeship). Wrocław (in Polish)

Duval TP, Waddington JM, Branfireun BA (2009) Towards calcareous wetland creation in flooded abandoned aggregate quarries: a 3-year field mesocosm study. Ecol Eng 36:586-595

EC (2012) Natural water retention measures. Science for environment policy. Eur Comm DG ENV 32:1-12
EEA (2009) Water resources across Europe-confronting water scarcity and drought, Report No 2/2009. Office for Official Publications of the European Communities, Luxembourg

Glapa W, Korzeniowski JI (2005) Mały leksykon górnictwa odkrywkowego (Little lexicon of open-casy mining). Wydawnictwa i Szkolenia Górnicze Burnat \& Korzeniowski, Wrocław (in Polish). Available online http://www.kgo.agh.edu.pl/wp-content/uploa ds/2012/12/mlgo.pdf. Accessed 29 Dec 2016

Gomez CM, Colentine D, Delacamara G, Strosspr P, Iacovides A, Kinell G, Söderquist T, Ungvari G, Fribourg-Blanc B (2013) Concept Note. Natural Water Retention Measures (NWRM) and the WFD and other Daughter Directives

GUS (2015) Environmental protection. Warszawa

Hinwood AL, Heyworth J, Tanner H, McCullough C (2012) Recreational use of acidic pit lakes - human health considerations for post closure planning. J Water Res Protect 4:1061-1070

Jawecki B (2004) Przykład pozytywnego oddziaływania melioracji wodnych na środowisko (An example of positive influence of water drainage systems on the environment). Wiadomości Melioracyjne i Łąkarskie 47(1):27-28 (in Polish)

Jawecki B (2012) Kopalnie w krajobrazie powiatu strzelińskiego - Wybrane przykłady zagospodarowania terenów poeksploatacyjnych (Mines in the landscape of Strzelin County-selected examples of post-mining area management). Archit Krajobrazu 4(37):24-34 (in Polish)

Jawecki B, Tokarczyk-Dorociak K, Pawęska K, Malczewska B, Bawiec A, Ochman D (2014) Directions for the reclamation and development of selected quarries in Strzelin county. In: Ochman D, Podoliński T, Jawecki B (eds) Environment protection in industrial areas. Wyd. Państwowej Wyższej Szkoły Zawodowej im. Witelona w Legnicy, pp 59-72

Kasztelewicz Z, Kaczorowski J (2009) Rekultywacja i rewitalizacja kopalń węgla brunatnego na przykładzie kopalni "Bełchatów" (Reclamation and revitalisation of lignite mines based on the example of Bełchatów mine). Górnictwo i Geoinżynieria 33(2):187-212 (in Polish)

Kasztelewicz Z, Hajdo S, Sypniowski S (2010) Górnictwo odkrywkowe a rekultywacja terenów pogórniczych. Cz. 1 (Open-cast mining and the reclamation of post-mining areas. Part 1). Probl Ekologii 14(1):22-32 (in Polish)

Kleeberg A, Grüneberg B (2005) Phosphorus mobility in sediments of acid mining lakes, Lusatia, Germany. Ecol Eng 24:89-100

Kowalewski Z (2008) Actions for small water retention undertaken in Poland. J Water Land Dev 12:155-167

Kumar RN, McCullough CD, Lund MA (2009) Water resources in Australian mine pit lakes. Min Technol 118(3-4):204-211

Kumar NR, McCullough CD, Lund MA, Larranaga SA (2016) Assessment of factors limiting algal growth in acidic pit lakesa case study from western Australia, Australia. Environ Sci Poll Res 23:5915-5924

Labant S, Staňková S, Weiss R (2013) Geodetic determining of stockpile volume of mineral excavated in open pit mine. GeoSci Eng 59(1): 30-40

Łabędzki L (2016) Actions and measures for mitigation drought and water scarcity in agriculture. J Water Land Dev 29(IV-VI):3-10

Linnerooth-Bayer J, Dubel A, Sendzimir J, Hochrainer-Stigler S (2015) Challenges for mainstreaming climate change into EU flood and drought policy: water retention measures in the Warta River Basin, Poland. Reg Environ Change 15:1011-1023

McCullough CD (2008) Approaches to remediation of acid mine drainage water in pit lakes. Int J Min Reclam Environ 22(2):105-119

McCullough CD, Lund MA (2006) Opportunities for sustainable mining pit lakes in Australia. Mine Water Environ 25:220-226

MIDAS (2012) System Gospodarki i Ochrony Bogactw Mineralnych (System for the protection and management of mineral sources). 
Available online http://geoportal.pgi.gov.pl/midas-web. Accessed 20 Sept 2016 (in Polish)

Ministry of the Environment (2013) Strategiczny plan adaptacji dla sektorów i obszarów wrażliwych na zmiany klimatu do roku 2020, z perspektywą do roku 2030 (Strategic adaptation plan for sectors and areas sensible t climate changes to the year 2020, with a perspective up to 2030). Warszawa (in Polish)

Mioduszewski W, Querner EP, Kowalewski Z (2014) The analysis of the impact of small retention on water resources in the catchment. J Water Land Dev 23(X-XII):41-51

Molenda T (2006) Górnicze środowiska akwatyczne-obiekty obserwacji procesów hydrologiczno-biologicznych (Mining aquatic environments as objects of the observations of hydrological and biological processes). Prace Naukowe Instytutu Górnictwa Politechniki Wrocławskiej 117(32):239-250 (in Polish)

Mosiej J (2014) Sustainable rural development policy in Poland-environmental aspects. Acta Region Environ 2:65-75

Mosiej J, Bus A (2015) New challenges in rural water management in Poland-selected problems. In: Raupelienè A (ed) Proc, 7th International Scientific Conf on Rural Development. Aleksandras Stulginskis University, Lithuania

NWMA (National Water Management Authority) (2010) Mapa Podziału Hydrograficznego Polski (Hydrographic Division Map of Poland). Available online: http://geoportal.kzgw.gov.pl. Accessed 20 Sept 2016 (in Polish)

PIG (2007) Wydzielenie rejonów wodno-gospodarczych dla potrzeb zintegrowanego zarządzania zasobami wód podziemnych i powierzchniowych kraju Region wodny Środkowej Odry. Obszar działalności RZGW we Wrocławiu. Podział na rejony wodnogospodarcze (Separation of water economic regions for integrated management of national groundwater and surface water resources. Mid-Oder water region. The area of operations of the Regional Water Management Authority. Division into water management regions). Polish Geological Inst-Polish Hydrogeological Survey, Warszawa (in Polish)

Polak K, Różkowski K, Pawlecka K, Kaznowska-Opala K, Chudzik W (2014) Prognoza zatapiania wyrobiska poeksploatacyjnego Świerki (a prognosis of the floodings of the Świerki post-mining pit). Przegląd Górniczy 70(2):31-36 (in Polish)

Ravazzani G, Giudici I, Schmidt C, Mancini M (2011) Evaluating the potential of quarry lakes for supplemental irrigation. J Irrig Drain Eng 137(8):564-571
RWMA (Regional Water Management Authority) (2016) Projekt Planu przeciwdziałania skutkom suszy w regionach wodnych Środkowej Odry, Izery, Metuje, Łaby i Ostrożnicy (Upa), Orlicy i Morawy (draft of the Plan of Counteracting Drought Effects in the water regions of mid-Oder, the Iser, Metuje, Elbe and Ostrożnica (Upa), Orlica and Morawa Rivers), Warszawa (in Polish)

Schultze M, Pokrandt K-H, Hille W (2010) Pit lakes of the central German lignite mining district: creation, morphometry and water quality aspects. Limnologica 40(2):148-155

Singleton VL, Jacob B, Feeney MT, Little JC (2013) Modeling a proposed quarry reservoir for raw water storage in Atlanta, Georgia. J Environ Eng 139(1):70-78

Soni AK, Mishra B, Singh S (2014) Pit lakes as an end use of mining: a review. J Min Environ 5(2):99-111

Szuflicki M, Malon A, Tymiński M (eds) (2016) Balance of mineral resources deposits in Poland as of the 31.12.2015, 2016. Polish Geological Institute (PIG), National Research Institute, Warszawa (in Polish)

Szwed M (2015) The elements of water balance in the changing climate in Poland. Adv Meteorol 2015:149674. https://doi. org/10.1155/2015/149674

Townsend FA, Helmers DP, Kingdon CC, McNeil BE, de Beurs KM, Eshleman KN (2009) Changes in the extent of surface mining and reclamation in the central Appalachians detected using a 19762006 Landsat time series. Remote Sens Environ 113(1):62-72

Wajs J (2015) Research on surveying technology applied for DTM modelling and volume computation in open pit mines. Min Sci 22:75-83

Walczykiewicz T (2014) Scenarios of water resources development in Poland up to 2030. Water Resour 41(6):763-773

Wężyk P, Szostak M, Krzaklewski W, Pająk M, Pierzchalski M, Szwed P, Hawryło P, Ratajczak M (2015) Landscape monitoring of postindustrial areas using LiDAR and GIS technology. Geodesy Cartogr 64(1):125-137

Wiatkowski M, Rosik-Dulewska C, Kuczewski K, Kasperek R (2013) Ocena jakości wody zbiornika Włodzienin w pierwszym roku funkcjonowania (The assessment of water quality in the Włodzienin reservoir in the first year of operation). Annu Set Environ Prot 15:2667-2682 (in Polish)

Witt EC (2016) Use of LiDAR point cloud data to support estimation of residual trace metals stored in mine chat piles in the old Lead Belt of southeastern, Missouri. AIMS Environ Sci 3(3):509-524 